\title{
Recenzje
}

DOI 10.35757/CIV.2016.18.18

\section{Legalne bezprawie}

Carl Schmitt: Legalność i prawomocność, Wydawnictwo Aletheia, Warszawa, 2015, ss. 215.

Pojęcie „państwa prawa” wydaje się czymś oczywistym. Wpisane do konstytucji większości krajów demokratycznych, stało się współcześnie standardem, a w perspektywie historycznej - najlepszą rękojmią, że obywatelowi nie grożą arbitralne decyzje rządzących. Legalność i prawomocność Carla Schmitta godzi w ten, jak by się mogło zdawać, ugruntowany porządek.

Książka jest kolejna wydana w Polsce praca Schmitta. Ten niemiecki prawnik i filozof, najbardziej znany jest jako autor Teologii politycznej ${ }^{1}$ W 1932 roku, czyli tuż przed dojściem Hitlera do władzy, opublikował Legalność i prawomocność. W pracy tej przedstawił krytykę koncepcji państwa prawa i związany $z$ nią stan Republiki Weimarskiej, który ocenił bardzo negatywnie. W istocie bowiem, państwo niemieckie po zakończeniu I wojny światowej w żadnym wypadku nie mogło zostać uznane za stabilne. Częste pucze krwawo tłumione przez policję, zmienność rządów (w la-

1 C. Schmitt: Politische Theologie: vier Kapitel zur Lehre von der Souveränität, 1922, wyd. pol.: idem: Teologia polityczna i inne pisma, wybór, przekład i wstęp M.A. Cichocki, Wydawnictwo Aletheia, Warszawa 2012. 
tach 1920-1924 było ich aż siedem), zamordowanie w 1922 roku ministra spraw zagranicznych Waltera Rathenaua - to wszystko mogło sprawiać wrażenie narastającego chaosu. Sytuację komplikowały ponadto dwa czynniki. Pierwszy stanowiły ekstremizmy prawicowe i lewicowe, które stale zagrażały weimarskiemu parlamentaryzmowi. Drugim czynnikiem był wielki kryzys ekonomiczny w 1929 roku, który niestabilność ówczesnych Niemiec tylko pogłębił i uczynił Republikę Weimarska jeszcze bardziej podatna na hasła ugrupowań skrajnych.

Wszystkie te wstrzassy i kryzysy polityczne otaczał szczególny klimat intelektualny, w którym myślenie o państwie i prawie zostało zdominowane przez pozytywizm prawniczy. I chociaż dyktatura, która zapanowała w Niemczech wraz $z$ dojściem Hitlera do władzy, mogła się kojarzyć raczej $z$ nieograniczona wola jednostki, faktem pozostaje, że konstytucja Republiki Weimarskiej z 1919 roku i wspomniany duch interpretacji prawa przetrwały władzę nazistowska i zostały usunięte dopiero w roku 1949.

Legalność i prawomocność jest już szósta wydana w Polsce praca Schmitta. Do wcześniejszych publikacji należą Teologia polityczna $i$ inne eseje, Teologia polityczna 2, Lewiatan $w$ teorii państwa Tomasza Hobbesa oraz Nauka o konstytucji. Obecnie zaś ukazała się rozprawa pod tytułem Dyktatura. Liczba tłumaczeń oraz fakt, że wszystkie one ukazuja się od nieco ponad dekady, pokazują wzmożone zainteresowanie filozofia Schmitta.

Omawiana tu książka Legalność i prawomocność nie jest praca obszerna. Składa się z wprowadzenia, w którym autor podaje podstawowa klasyfikację państw w zależności od ich stosunku do źródeł prawa i jego stosowania, oraz trzech następujacych po nim rozdziałów. Wydanie polskie zostało ponadto wzbogacone tekstem konstytucji Republiki Weimarskiej, która stanowi dla Schmitta główny punkt odniesienia. Podczas gdy wspomniane wprowadzenie zawiera tylko aparat pojęciowy, którym autor posługuje się w kolejnych partiach książki, to pozostałe rozdziały sa już kluczowe dla Schmittowskiej krytyki państwa prawa w ogólności oraz kon- 
stytucji Republiki Weimarskiej jako egzemplarza takiej koncepcji ustrojowej.

Skoro jednak mamy do czynienia $z$ praca interwencyjna, za pomoca której intelektualista wyraził swoje zaniepokojenie tym, co hic et nunc działo się wokół niego, to powstaje pytanie, czy nie jest to książka przebrzmiała, której wartość ogranicza się do roli krytycznego komentarza do przedwojennej niemieckiej ustawy zasadniczej. Otóż, wręcz przeciwnie! Jeżeli czytelnik prześledzi zawartą w książce argumentację autora, $z$ łatwością dostrzeże ponadczasowy wymiar tej pracy, której aktualność ujawnia się zwłaszcza w kontekście współczesnego kryzysu państwa prawa oraz debaty wokół pozytywizmu prawniczego.

\section{Państwo prawa, czyli parlamentarne państwo prawodawcze}

Wprowadzenie do Legalności i prawomocności zawiera Schmittowskie ujęcie państwa prawa. Zgodnie $z$ nim należy przyjąć, iż choć historycznie w każdym państwie istniało jakieś prawo i jakieś unormowanie życia społecznego, to jednak dopiero XIX wiek zrodził typ państwa, w którym wola wspólnoty znalazła swoje odzwierciedlenie w ogólnych unormowaniach, a więc w konstytucji. W takiej wspólnocie politycznej mieli rządzić nie ludzie, ale przepisy oraz normy. Precyzyjnej można powiedzieć, że przepisy nie tyle rządziły, ile obowiązywały. Filozof pisał: „Kto rządzi i włada, działa "na gruncie prawa" lub "w imieniu prawa". Nie czyni nic kompetentnego prócz wdrażania obowiazującej normy. Prawo stanowi instancja prawodawcza, która jednak nie rządzi, a tego prawa sama nie wdraża ani nie stosuje, lecz właśnie ustanawia tylko obowiazujące unormowania, w których imieniu potem podporządkowane prawu władze wykonawcze moga sprawować władzę państwową"2.

Carl Schmitt wymienia trzy rodzaje władzy: legislatywę, egzekutywę i judykaturę. Pierwsza $z$ nich miała przepisy uchwalać, druga

2 C. Schmitt: Legalność i prawomocność, s. 8-9. 
wcielać w życie, a trzecia kontrolować ich stosowanie. Ponadto taki typ państwowości charakteryzował się również jednolitościa prawa. O ile w przeszłości brano pod uwagę prawo zwyczajowe, wcześniejsze ustawodawstwo, normy prawa kościelnego i naturalnego, o tyle $\mathrm{w}$ parlamentarnym państwie prawa prawodawca uzyskał monopol na legalność. Carl Schmitt uznał pojęcie legalności za kluczowe i zwrócił uwage na problem prawomocności tego, co legalne na gruncie prawa. Trudność polegała na tym, że pytanie o prawomocność straciło $\mathrm{w}$ tym modelu prawa sens. Wszystko to, co legalne, było także ex definitione prawomocne. Lecz wobec tego, co należało zrobić wówczas, gdyby powstało realne zagrożenie tyranią lub dyktaturą? I czy rzeczywiście wspomniany monopol prawodawczy był zachowywany w przepisach prawa i samej praktyce politycznej tak jednorodnie, jak to zdawałaby się sugerować teoria? Te dwa pytania były dla Carla Schmitta punktem wyjścia do rozważań w kolejnych czterech rozdziałach, które składają się na Legalność i prawomocność.

\section{Jednakowa chance}

Za istotną cechę parlamentaryzmu Carl Schmitt uznał równy dostęp do władzy dla rozmaitych stronnictw politycznych. Każde $z$ nich powinno mieć jednakową szansę zdobycia większości parlamentarnej. Kluczowe tu słowo, czyli termin chance, Schmitt pozostawił $\mathrm{w}$ swoim oryginalnym brzmieniu, mając na uwadze jego specyficzne znaczenie $\mathrm{w}$ języku angielskim, jako mieszanki szczęśliwego przypadku i legalności. Czy jednak parlamentaryzm owa chance zachowywał? Autor zwrócił uwage na to, że wpisany do konstytucji niemieckiej mechanizm uchwalania prawa moca arytmetycznej większości pozostawał niezgodny z daniem jakiejkolwiek chance opozycji. Ci, którzy zdobyli większość parlamentarna, mogli, na przykład, swoich przeciwników w majestacie obowiazującego prawa zdelegalizować. Innymi słowy, Schmitt wskazał, że to, co stanowiło jedna $z$ istotnych podstaw systemu, czyli jednakowa 
chance dla wszystkich opcji politycznych, mogło w ramach samego systemu zostać usunięte. Co więcej, nie była to jedyna sprzeczność parlamentarnej legalności.

\section{Trzej nadzwyczajni prawodawcy}

W swojej analizie konstytucji weimarskiej Schmitt doszedł do wniosku, że współczesny mu system prawny w Niemczech zawierał w sobie możliwość odwołania się aż do trzech nadzwyczajnych „prawodawców”. Po pierwsze, autor zwrócił uwagę, że parlament, w którym jedna $z$ opcji politycznych uzyskałaby większość dwóch trzecich głosów, stałby się władzą absolutną. Zagrożenie to, chociaż rzeczywiste, miało w sobie także osobliwa niekonsekwencję, która kryła się w samym systemie legalności. Otóż w sytuacjach zwyczajnych parlament uchwalał ustawy zwykła większościa, czyli potrzebowano ponad połowy głosów. Gdy jednak chodziło o zmiany w konstytucji, zachodziła konieczność osiągnięcia większości kwalifikowanej, do której wymagano ponad dwóch trzecich głosów. Oczywiście, przemawiały za tym pewne racje pragmatyczne, trudno jednak było wskazać racje merytoryczne. Cóż takiego miało bowiem sprawiać, że parlament tracił właściwa mu godność i autorytet, gdy zmieniał coś w ustawie zasadniczej, a zachowywał ja wobec zwykłych ustaw i uchwał? Jeżeli przełożyć na procenty zachodzącą między tymi przypadkami różnicę w liczbie posłów niezbędnych do uchwalenia nowego prawa, to okazuje się, że do zmiany konstytucji potrzebne byłoby zaledwie o 15,7 proc. parlamentarzystów więcej niż do uchwalenia zwykłej ustawy. Na czym polega zatem - pyta Schmitt - siła tych 15,7 proc., że liczba ta potrafi ukonstytuować wyższego prawodawcę (w porównaniu do zwykłego) i silniejszą legalność?

Po drugie, Schmitt zauważył, że poza parlamentem istniał także inny prawodawca, a mianowicie wyrażona w plebiscycie wola narodu. Co ciekawe, naród jako suweren wydawał się prawodawca wyższym niż parlament, który przecież sam był powoływany na 
czteroletnią kadencję moca wyborów powszechnych, czyli plebiscytu. Nasuwał się zatem wniosek, że system demokracji parlamentarnej był jedynie deklaratywnie systemem jednolitym, a w rzeczywistości oznaczał współistnienie dwóch form: ratio parlamentu i charakterystycznego dla państwa jurysdykcyjnego voluntas suwerena, którym pozostawał naród.

Zdaniem Schmitta, można było wskazać także trzeciego prawodawcę. Otóż praktyka polityczna Republiki Weimarskiej wytworzyła pewna interpretację tych artykułów ustawy zasadniczej, które w przypadku zagrożenia bezpieczeństwa publicznego, przyznawały prezydentowi Rzeszy uprawnienia do wprowadzania stanu wyjąkowego, zawieszenia praw podstawowych i władzę przywracania porzadku, nawet przy użyciu sił zbrojnych. Chociaż wszelkie podjęte $\mathrm{w}$ takich okolicznościach decyzje miały być wyłącznie tymczasowe i winny podlegać kontroli parlamentu, to jednak praktyka prowadziła do zatarcia różnicy między zarządzeniem a ustawą. Sprawiło to, że zarządzenia prezydenckie stawały się równe aktom prawnym, które uchwalał parlament. W rezultacie głowa państwa stała się, jak to ujmuje Schmitt, prawodawca stanu wyjątkowego (ratione necessitatis). W ten sposób aż trzy siły: parlament, lud oraz prezydent mogły w wyjątkowych sytuacjach przejaćc całość władzy, nie naruszając formalnych ram prawa stanowionego ani konstytucji. Historycznie zreszta, możliwość ta została wykorzystana. Adolf Hitler, dochodzac do władzy, zachował demokratyczna fasadę, co nie przeszkodziło mu w przejęciu pełni władzy.

\section{Wyparta lekcja z przeszłości}

Przedstawiając zarzuty wobec liberalnej demokracji, Carl Schmitt wykazał, że autorytarne tendencje międzywojnia nie były czymś opozycyjnym względem demokracji, lecz wyrastały z jej kryzysu, majac za podglebie to, co stanowiło jej najistotniejszy składnik - parlamentarne państwo prawodawcze. 
Według mnie, książka Legalność i prawomocność Carla Schmitta jest pozycja ze wszech miar godna uwagi. Jej zakres nie ogranicza się do analizy historycznego dokumentu prawnego, choćby $z$ tego powodu, że przepisy zawarte $\mathrm{w}$ analizowanej przez niemieckiego jurystę konstytucji pozostały zbliżone do wielu współczesnych ustaw zasadniczych. Współczesnemu czytelnikowi najmniej zajmujący może wydawać się rozdział o trzecim prawodawcy i znaczeniu prezydentury $\mathrm{w}$ sytuacjach nadzwyczajnych. Na tym przykładzie jednak udało się ukazać kruchość liberalnej demokracji, która zawiera sprzeczne zasady władzy. Historycznie zaś, argumentacja przedstawiona przez Carla Schmitta pozwala przybliżyć się do odpowiedzi na pytanie, jak mogło dojść do tego, że demokratyczne Niemcy w majestacie przedwojennego legalizmu przekształciły się w totalitarne państwo nazistowskie.

Ponadto, do zalet Legalności i prawomocności należy spójność i przejrzystość wywodu, wiedza prawnicza autora gwarantuje zaś rzetelność analizy przepisów konstytucyjnych. Jednak tym, co przesądza o niesłabnącej aktualności tych analiz, jest siła, $z$ jaka autor wykazał, iż „uświęcone” formy życia politycznego wcale aż tak stabilne nie sa. Co więcej, pozostają one wątłe i wrażliwe na zakłócenia. Jeżeli bowiem książki maja pobudzać do myślenia, to $z$ pewnością rolę tę najlepiej odgrywaja pozycje, które pokazuja, że rzeczywistość wokół nas nie jest tak oczywista, jak mogłoby się wydawać. Legalność i prawomocność $z$ pewnościa do takich książek należy.

Michat Rzeczycki

Michat Rzeczycki - student filozofii w Instytucie Filozofii Uniwersytetu Warszawskiego, interesuje się filozofią polityczną. 